\title{
A Review of the Ubiquity of Ascomycetes Filamentous Fungi in Relation to Their Economic and Medical Importance
}

\author{
Mary Augustina Egbuta1,2*, Mulunda Mwanza3 ${ }^{3}$, Olubukola Oluranti Babalola1 \\ ${ }^{1}$ Department of Biological Sciences, Faculty of Agriculture, Science and Technology, North-West University, Mafikeng Campus, \\ Mmabatho, South Africa \\ ${ }^{2}$ Southern Cross Plant Science, Southern Cross University, Lismore Campus, Lismore, Australia \\ ${ }^{3}$ Department of Animal Health, Faculty of Agriculture, Science and Technology, North-West University, Mafikeng Campus, \\ Mmabatho, South Africa \\ Email: ^egbutamary@gmail.com, mulunda.mwanza@nwu.ac.za, olubukola.babalola@nwu.ac.za
}

How to cite this paper: Egbuta, M.A., Mwanza, M. and Babalola, O.O. (2016) A Review of the Ubiquity of Ascomycetes Filamentous Fungi in Relation to Their Economic and Medical Importance. Advances in Microbiology, 6, 1140-1158.

http://dx.doi.org/10.4236/aim.2016.614103

Received: October 31, 2016

Accepted: December 25, 2016

Published: December 28, 2016

Copyright (c) 2016 by authors and Scientific Research Publishing Inc. This work is licensed under the Creative Commons Attribution International License (CC BY 4.0).

http://creativecommons.org/licenses/by/4.0/

\begin{abstract}
Filamentous fungi are found in different habitats in the environment including, air, water and soil. This group of fungi contains organisms from different classes under the sub-phylum Pezizomycotina. They occur in mixtures such that you find many genera of filamentous fungi dominating a particular habitat or substrate. The wide distribution of filamentous fungi has resulted in it being used for different purposes. This review aims to analyse the different genera of fungi species referred to as filamentous fungi and their relevance economically and medically.
\end{abstract}

\section{Keywords}

Filamentous, Fungi, Air, Soil, Water, Distribution

\section{Introduction}

Filamentous fungi which is a member of a large group of eukaryotes that includes some yeasts, moulds and some mushrooms, is also classified as a kingdom and separated from plants, protists, animals and bacteria. With cell walls containing chitin, a main disparity from plant cell walls which contain cellulose and bacterial cell walls, fungi are abundant in the environment and inconspicuous because of their small structures and their cryptic lifestyles on substrates they inhabit [1]. Naturally occurring in different parts of the environment and ecosystem, filamentous fungi which belong to a sub-kingdom of fungi referred to as "Dikarya" are some of the most abundant fungi known [2]. 
Also referred to as molds, filamentous fungi are so called because they possess hyphae which form branches making up their mycelia, growing like threadlike structures. They are reported to occur naturally as well as contaminate different surfaces both indoors and outdoors. As a result of their vast occurrence in the environment, these types of fungi have been investigated from over the years for their positive and negative uses for mankind [3] [4] [5] [6]. Due to the ubiquitous occurrence of filamentous fungi and their applications in different sectors of mankind economy, this review aims to discuss in details the wide occurrence of filamentous fungi in our environment, describing the different genera of filamentous fungi in existence as well as analyzing the positive and negative importance of these groups of fungi to mankind.

\section{Filamentous Fungi}

As was mentioned in the introduction, one major characteristic contributing to classifying fungi as filamentous fungi is the ability to possess hyphae. A high number of known filamentous fungi tend to originate from the sub-Phylum "Pezizomycotina" which falls under the Phylum "Ascomycota", also a part the sub-kingdom Dikarya [2] [7]. As indicated in the chart in Figure 1, filamentous fungi encompasses many genera of fungi including Aspergillus, Penicillium, Fusarium, Cladosporium, Emericella, Eurotium, Paecilomyces, Curvularia, etc. with Aspergillus, Penicillium, Fusarium, Alternaria and Cladosporium occurring most and more investigated than the other genera [8]. In the following sections the different genera of fungi in the group of filamentous fungi are mentioned and described taking cognisance of the most occurring and less occurring genera.

\subsection{Aspergillus}

A member of the Trichocomaceae family in the order Eurotiales, Aspergillus are reportedly the most abundant and widely distributed filamentous fungi globally although

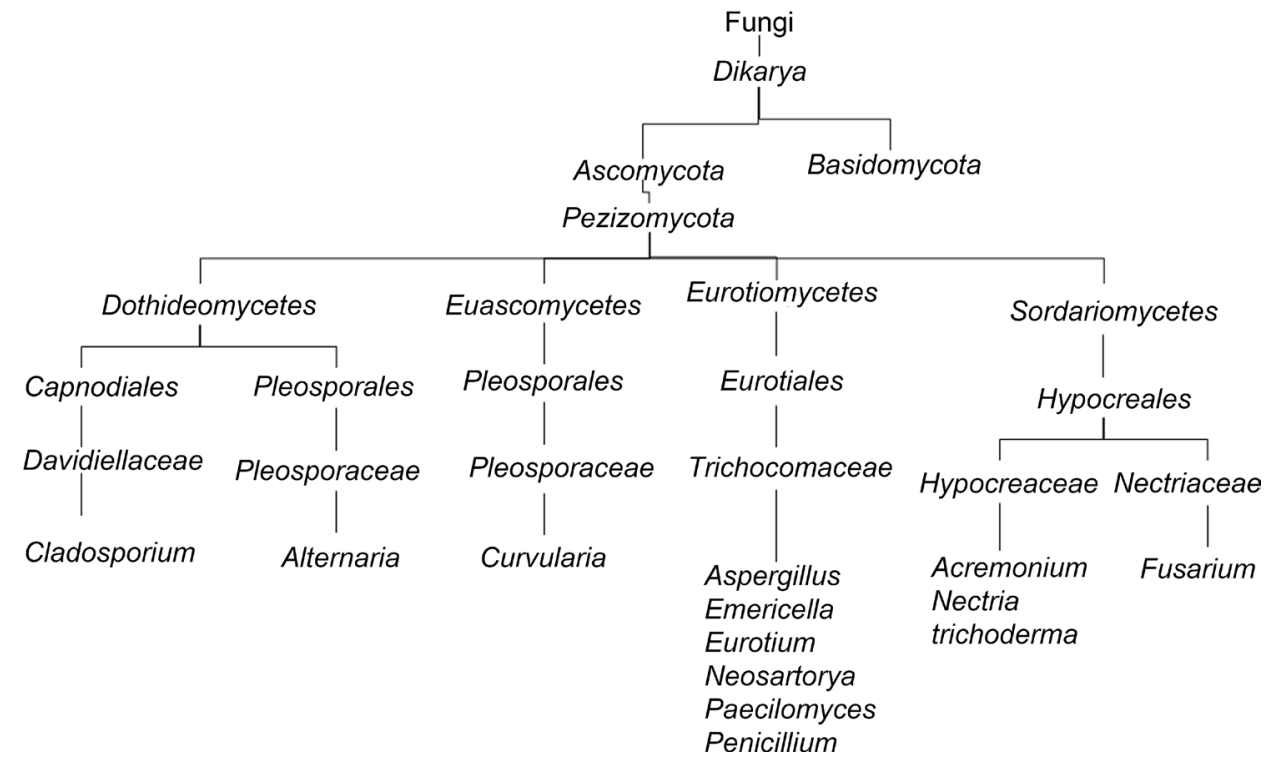

Figure 1. Chart showing distribution of filamentous fungi in phylum Ascomycota ([1] [2] [7]). 
they are more frequent in warmer regions occurring more frequently in mild zones than in warmer regions (Klich, 2002). Usually regarded as a soil fungi [9] they are a part of the filamentous fungi family, ubiquitous, cosmopolitan, found in nature and commonly isolated from soil, plant debris and indoor environment. They have the ability to grow at lower water activity and occur on storage food and feed which turn moldy. Some species of Aspergillus have been accepted to be mitosporic without any known sexual spore production while a teleomorphic state has been described for other species of Aspergillus [2]. With their characteristic dark colors, sometimes black, grey or green and in other cases white or milky colored, there are over 185 species of the genera $A s$ pergillus in existence of which, A. fumigatus is the most commonly isolated species, followed by A. flavus and A. niger [10]. Other species of Aspergillus so far isolated, though less commonly so, include $A$. clavatus, A. glaucus group, A. oryzae, A. versicolor, A. nidulans, A. terreus, A. ustus, and a host of others [10].

\subsection{Fusarium}

These group of filamentous fungi widely distributed in plants, the soil and known to contain a range of plant-pathogenic fungal species have been in existence for the past two centuries as it was first introduced in 1809 [11]. They are primary plant pathogens which require high water activity for growth and are characterized by production of septate, fusiform to crescent shaped macroconidia with or without microconidia [11] [12]. Aside from their ability to act as plant pathogens, Fusarium species have been linked to wide range of diseases and infections in humans and animals [13]. Commonly occurring species of the genus Fusarium include Fusarium verticilliodes, Fusarium graminearium, Fusarium proliferatum, Fusarium sporotrichiodes, Fusarium solani, Fusarium chlamydosporum amongst others [11].

\subsection{Penicillium}

Penicillium species are among the most common decomposers in nature. This genus of Ascomycetes fungi are closely related to Aspergillus species but in general are less thermo-tolerant and are most prominent ecologically in cooler areas, though they are by no means absent in the tropics [14]. Genus Penicillium is characterized by the production of conidia in a structure termed a penicillus and widely distributed in the environment posing the argument of greater economic importance between Penicillium and Aspergillus. Although it is certain that Penicillium is more diverse in terms of species and range of habitats as they have the ability to grow in almost any environment [12]. A wide range of Penicillium species occur and as such include $P$. citreonigum, $P$. polonicum, $P$. digitatum, $P$. chrysogenum, $P$. roqueforti, $P$. citrinum, $P$. janthinellum, $P$. simplicissimum, $P$. aurantiogriseum, $P$. camemberti, $P$. verrucosum and $P$. expansum amongst others [12].

\subsection{Cladosporium}

This genus is a commonly isolated genus belonging to the filamentous fungi group with 
its species occurring both as saprophytes and as plant pathogens; and producing olivegreen to brown or black colonies [12]. They occur mostly in outdoor environment and only occur indoors on moist surfaces. Cladosporium species occur as pathogens on fresh fruit with one of the species Cladosporium fulvum being a common cause of tomato leaf mold [15]. Some common Clasdosporium species include C. fulvum, C. cladosporioides, C. herbarum, C. salinae, C. spinulosum, C. fusiforme, C. arthropodii amongst over 30 known species.

\subsection{Alternaria, Acremonium and Curvularia}

Alternaria species are reported to be major plant pathogens causing at least $20 \%$ of agricultural spoilage [16]. A member of the Pleosporaceae family, this genus include species that are found to occur almost everywhere indoors and outdoors growing thick green, black or grey colonies. Some of the isolated Alternaria species from water, food, air and plants include $A$. alternata, A. molesta, A. solani, A. japonica, A. longipes, and A. infectoria.

The genus Acremonium is reported to be a large and varied genus characterized by fine and hyaline hyphae which are produced mostly by simple phialides and single-celled conidia [14]. Commonly isolated from dead plant materials and soil, this genus comprises of up to 100 species with Acremonium strictum reported as one of the most common species isolated from food.

Mostly found in tropical regions and seldom in temperate zones, the genus Curvularia is a pathogen of many plant species and soil. This genus has the ability to withstand very high temperatures up to $40^{\circ} \mathrm{C}$ which is the reason for its predominance in tropical regions [12]. Curvularia species are not as numerous as the other genera of filamentous fungi group and have been mostly isolated from soil and plant tissues/seeds. Some of Curvularia species include C. clavata, C. penniseti, C. protuberata, C. trifolii, C. tuberculata, $C$. lunata, $C$. pallescens, $C$. ovoidea, with $C$. lunata and $C$. pallescens commonly isolated [12].

\subsection{Emericella and Eurotium}

The genus Emericella was first mentioned in 1857 [17] and is a teleomorph of Aspergillus species. Described to be the sexual state of Aspergillus species and because of this closeness species of this genus are likely to be present alongside their related Aspergillus species during long term growth [18] [19]. Producing ascopores (conidia) that are brightly colored with smooth to roughened texture [2], species of the Emericella genus grow rapidly and are common in tropical and sub-tropical regions of the world [20]. The genus includes over thirty (30) species such as Emericella olivicola, E. nidulans, E. stellamaris, E. filifera, E. quadrilineata, E. discophora, etc. [18] [19].

Closely related to the genus Emericella and also a member of the family Trichocomaceae, the genus Eurotium is another anamorph of Aspergillus species commonly found in tropical and sub-tropical regions in the world [2] They are characterized by spherical to ellipsoidal spores that grow in chains and are rough walled. Possessing a 
moderately rapid growth rate, colonies of Eurotium species are usually yellow or dull green to bluish green and have the ability to grow very well even at low water activity [21]. Common Eurotium species include Eurotium amstelodami, E. herbariorium, E. repens, E. rubrum and others [21] [22].

\subsection{Paecilomyces}

Also a member of the same family as Aspergillus, Eurotium, Emericella and Penicillium, the genus Paecilomyces is often confused with the Penicillium genus because of their close morphological resemblance [2]. Growing rapidly, some species of this genus are regarded as thermophilic organisms due to their ability to grow well at high temperatures up to $50^{\circ} \mathrm{C}$ [23]. Some commonly isolated Paecilomyces species include Paecilomyces variotii [24], P. lilacinus [23] [25] and P. fulvus [26].

\section{Distribution of Filamentous Fungi in the Environment}

As a result of their ubiquitous nature, filamentous fungi are widely distributed in the environment. The vast variety of substrates on which filamentous fungi are able to grow on has also contributed to their wide distribution in the environment worldwide [27]. Although most filamentous fungi require high temperatures and high humidity like the Aspergillus species [2] which results in their species occurring mostly in hot and humid regions of the world, some fungi like the Penicillium species also have the ability to grow in temperate areas [2] causing such species to occur in colder areas of the world. In this case, filamentous fungi can be found in almost every part of the environment. In continuation of this review, we would evaluate their distribution in three habitats of the environment: air, soil and water. This is illustrated further in Table 1.

\subsection{Air}

Present in both outdoor and indoor air, species of the filamentous fungi family are widely distributed in air [36] [63]. They have been isolated from air samples collected from different areas such as hospitals, outdoor areas and households [37] [63] [64]. Among the many species of filamentous fungi, the Aspergillus, Penicillium and Cladosporium genera have been mostly isolated with lesser occurrence of Fusarium and other species [65]. Within the genus Aspergillus, A. flavus, A. niger and A. fumigatus are the most common species isolated from air samples collected from both indoor and outdoor areas [36] [64] [66].

\subsection{Soil}

The growth pattern of filamentous fungi mycelia which is mainly hyphelial extension and branching has contributed to the potential of a wide range of filamentous fungi species to be found occurring naturally in soil from different regions of the world [67]. The occurrence of filamentous fungi such as Penicillium, Aspergillus, Trichoderma, Curvularia, Paecilomyces species, etc. have been reported in soil from semi-arid areas characterized by low rainfall [35]. The presence of a variety of filamentous fungi species 
Table 1. Distribution of filamentous fungi in the environment.

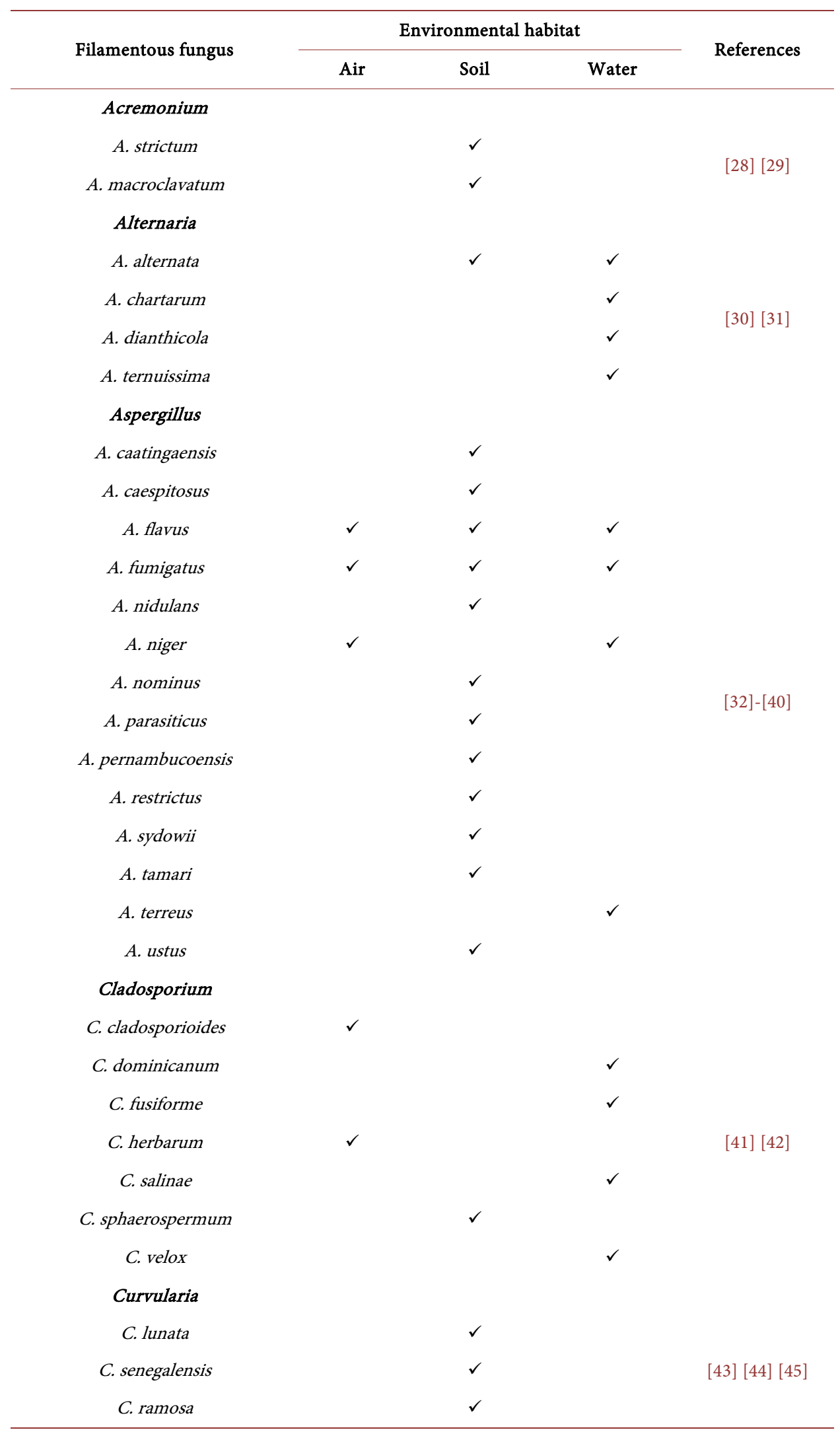




\section{Continued}

Emericella

E. rugulosa

E. quadrileanata

Eurotium

E. amstelodami

E. chevalieri

E. herbariorium

E. rubrum

Fusarium

F. acuminatum

F. avanaceum

F. chlamydosporum

F. concolor

F. culmorum

F. equiseti

F. graminearum

F. nivale

F. oxysporum

F. proliferatum

F. sambucinum

F. solani

F. subglutinans

F. sporotrichiodes

F. tricinctum

F. verticilliodes

Penicillium

P. citrinum

P. commune

P. chrysogenum

P. glaber

P. lanosum

P. marneffei

P. notatum

P. oxalicum

P. sclerotiorum

P. spinulosum

Paecilomyces

P. lilicanus

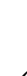

$\checkmark$

$\checkmark$
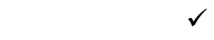

[46]-[54]

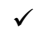

[33]

$\checkmark$

$\checkmark$
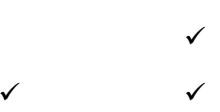

$\checkmark$
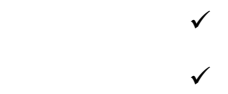
have also been reported in soil from colder regions like the Antarctica by Kurek et al. [68] and Hughes et al. [69]. Although humidity is one condition which favors growth of filamentous fungi, some species of this family of fungi such as Aspergillus, Cladosporium, Penicillium and Alternaria species are able to thrive in soil from desert areas including areas that have not recorded rainfall in decades [70].

\subsection{Water}

Odor and taste in water has been attributed to the presence of fungi in it [71] [72]. Fungal biomass has been reported in water systems from different parts of the world [73] [74]. A range of genera of filamentous fungi have been isolated from different sources of water. These sources include rivers, underground water, dead sea water, tap water and bottled water. Yamaguchi et al. [75], Warris et al. [76] and Okpako et al. [77] reported isolation of Penicillium, Aspergillus, Cladosporium, Alternaria and other genera of filamentous fungi form tap water and drinking water. Occurrence of filamentous fungi genera with Penicillium, Cladosporium and Alternaria species dominating has also been isolated from bottled and processed water [77]. Filamentous fungi isolated from rivers and underground water include Penicillium species and other genera of this family [78], also, they occur in water high in salts and minerals [79]. Amongst the commonly occurring filamentous fungi genera, Fusarium species have been seldom isolated from water [71] [76] [80] with little or nothing reported in regards to Fusarium occurrence in water.

\section{Economic Importance of Filamentous Fungi}

Filamentous fungi are currently being used in the manufacturing and agricultural sectors all over the world. They are a source of raw materials for food, chemical, pharmaceutical and cosmetic industries [81] [82] [83]. Apart from their positive impacts, filamentous fungi can have negative economic impacts, thus being beneficial or detrimental economically. There is therefore a need to evaluate the economic advantages and disadvantages of filamentous fungi as presented in Table 2.

\subsection{Agriculture}

Filamentous fungi have been implemented as bioremediation agents [96] [97], degrading the contents of high chemically contaminated soil and thereby reducing toxicity of the soil. Species such as A. flavus and Paecilomyces farinosus have the ability to degrade Benzo [a] pyrene in soil (Romero et al. [84], whereas, Fusarium species can also bio-remediate soils high in polycyclic aromatic hydrocarbons [98]. The discovery of filamentous fungi activity in bioremediation of soil has prompted more studies of other naturally occurring soil filamentous fungi for bioremediation properties. One example of such is a study by Kurniati et al. [85] whereby filamentous fungi were investigated for reducing mercury in soil. These micro-organisms have also made positive impacts in their use as biocontrol agents against microbes and harmful compounds in plants and crops [89] [90] [99]. The potential of using filamentous fungi in biofuel production 
Table 2. Economic applications of filamentous fungi.

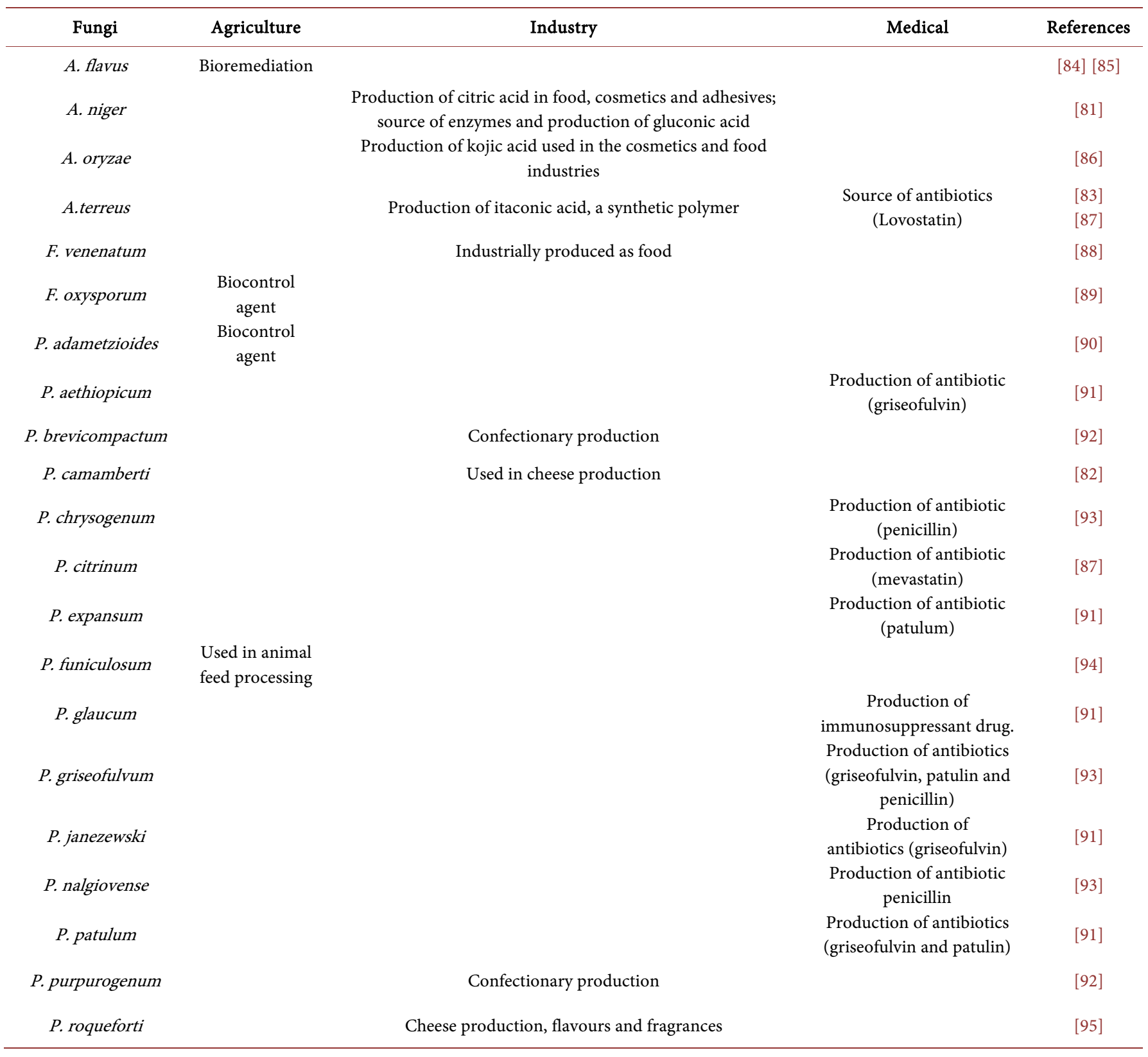

has been investigated by Zheng et al. [100] and found to be feasible.

Some genera of filamentous fungi are reported in association with plant diseases and food spoilage in agriculture, contaminating crops at different stages of production [101]. Aspergillus species such as A. niger, A. flavus, A. fumigatus, A. alliaceus, A. carbonarius and A. ochraceus, as well as Fusarium, Penicillium and Alternaria genera are some examples that cause infections and contamination in plants and plant products respectively [26] [101] [102]. Fungal Infection/ contamination of food crops and food products results to a reduced nutritional value and quality of food crops [102] as well as subsequent economical losses [103]. 


\subsection{Manufacturing Industry}

In the paper manufacturing industry, filamentous fungi are implemented in the manufacture of high quality paper suitable for writing and printing [104], with reports that fungal mycelium make up about $10 \%$ of good paper quality content. The use of filamentous fungi in industries to compost industrial waste has also been reported by Mohammad et al. [105] indicating the contribution of these micro-organisms in disposal of waste generated from processing palm produce.

\subsection{Food Industry}

As a source of different enzymes [106] [107] [108], filamentous fungi are currently being used in different areas of the food manufacturing industry [2]. The activity of filamentous fungi during fermentation has contributed to its use in food manufacturing. An example of such is the use of $A$. niger for fermentation to produce citric acid [109] [110], which is one of the main sources of industrially produced citric acid. Also, the ability of filamentous fungi to produce enzymes, vitamins, lipids, proteins, flavors and other valuable compounds which are implemented in food production [111].

\subsection{Pharmaceutical/Medical}

Chemical compounds produced by filamentous fungi are important to the medical and pharmaceutical industry. This importance can be beneficial or detrimental properties of the compounds and their effects on both humans and animals. Filamentous fungi produce different metabolites that have proven to have different inhibitory effects in metabolic pathways. An example of such compounds are the statins which include lovastatin produced by $A$. terreus [112], mevastatin produced by $P$. citrinum [113] and pravastatin produced by $P$. chrysogenum [114]. The function of statins is to inhibit the enzyme hydroxymethyl glutaryl-Coenzyme A (HMG-CoA) reductase which is the first enzyme in cholesterol biosynthesis [113], thereby lowering blood cholesterol levels in individuals who have high cholesterol levels. Some other filamentous fungus (Fusarium oxysporum) have been investigated and found to produce Cyclosporin- $\mathrm{A}$ (an immunosuppressant) currently used in the treatment of cancer, organ transplant patients and in the treatment of auto-immune diseases including AIDS [115].

The ability of filamentous fungi to inhibit microbial growth has also been investigated. He et al. [116] found that filamentous fungi species could produce pyrrocidines $\mathrm{A}$ and $\mathrm{B}$, which are effective antibiotics against gram-positive bacteria including resistant strains. Echinocandins produced by Aspergillus species have been reported by Goswami et al. [117] to inhibit an enzyme that facilitates fungal cell wall formation in fungal species. Other anti-microbial activities of filamentous fungi reported include inhibition of Escherichia coli, Staphylococcus aureus and Candida albicans [118] and anti-oxidant activities [119]. Filamentous fungi biofilm are currently used as biocatalysts for the production of human drug metabolites since they have been proven to have longer effective time [120]. This is a process required for drug development which contributes to assessing toxicity of a drug in pharmacokinetic studies. 


\section{Conclusion}

This review has reported that the distribution of filamentous fungi in our environment is an obvious fact that cannot be disputed. The eventual result of this distribution is the implementation of filamentous fungi by mankind in different industries. Considering the pros and cons of filamentous fungi discussed in this review, it is evident that filamentous fungi can be both beneficial and detrimental to the human race. In that regard, more research is encouraged to exploit the positive uses of these groups of diverse organisms as well as carry out studies to investigate ways of reducing their harmful effects.

\section{Acknowledgements}

The authors wish to appreciate North-West University for providing the academic environment to prepare this review and the National Research Foundation (NRF), for providing funding for the study.

\section{Conflict of Interest}

The authors hereby declare that there are no conflicts of interest.

\section{References}

[1] Pitt, J.I., Samson, R.A. and Frisvad, J.C. (2000) List of Accepted Species and Their Synonyms in the Family Trichocomaceae. In: Samson, R.A. and Pitt, J.I., Eds., Integration of Modern Taxonomic Methods for Penicillium and Aspergillus Classification, Harwood, Amsterdam, 9-49.

[2] Kirk, P.M., Cannon, P.F., Minter, D.W. and Stalpers, J.A. (2008) Dictionary of the Fungi. CSIRO Publishing, Australia.

[3] Bennett, J.W. (1998) Mycotechnology: The Role of Fungi in Biotechnology. Journal of Biotechnology, 66, 101-107. https://doi.org/10.1016/S0168-1656(98)00133-3

[4] Bennett, J.W. and Klich, M. (2009) Mycotoxins. In: Schaechter, M., Ed., Encyclopedia of Microbiology, 3rd Edition, Academic Press, Oxford, 559-565. https://doi.org/10.1016/B978-012373944-5.00333-3

[5] Sauer, M., Porro, D., Mattanovich, D. and Branduardi, P. (2008) Microbial Production of Organic Acids: Expanding the Markets. Trends in Biotechnology, 26, 100-108. https://doi.org/10.1016/j.tibtech.2007.11.006

[6] Ward, O.P. (2012) Production of Recombinant Proteins by Filamentous Fungi. Journal of Biotechnology Advances, 30, 1119-1139.

[7] Moretti, A.N. (2009) Taxonomy of Fusarium Genus, a Continuous Fight between Lumpers and Splitters. Proceedings of the National Academy of Sciences, 117, 7-13. https://doi.org/10.2298/zmspn0917007m

[8] Pitt, J.I. and Hocking, A.D. (1997) Primary Keys and Miscellaneous Fungi. Fungi and Food Spoilage, 2nd Edition, Blackie Academic and Professional, London, Weinheim, New York, Tokyo, Melbourne, Madras, 59-171. https://doi.org/10.1007/978-1-4615-6391-4_5

[9] Barkai-Golan, R. (2008) Chapter 6-Aspergillus Mycotoxins. In: Rivka, B.-G. and Nachman, P., Eds., Mycotoxins in Fruits and Vegetables, Academic Press, San Diego, 115-151. https://doi.org/10.1016/B978-0-12-374126-4.00006-1 
[10] Klich, M.A. (2002) Introduction; Economic and Medical Importance of Aspergillus. Identification of Common Aspergillus Species, Centraalbureau voor Schimmelculture, Utrecht, $1-16$.

[11] Leslie, J.F. and Summerell, B.A. (2006) The Fusarium Laboratory Manual. Blackwell Publishing, Hoboken, 1-2. https://doi.org/10.1002/9780470278376

[12] Pitt, J.I. and Hocking, A.D. (1997) Primary Keys and Miscellaneous Fungi. In: Pitt, J.I. and Hocking, A.D., Eds., Fungi and Food Spoilage, 2nd Edition, Blackie Academic and Professional, London, 59-171. https://doi.org/10.1007/978-1-4615-6391-4_5

[13] Nucci, M. and Anaissie, E. (2007) Fusarium Infections in Immunocompromised Patients. Clinical Microbiology Reviews, 20, 695-704. https://doi.org/10.1128/CMR.00014-07

[14] Howard, D.H. (2003) Pathogenic Fungi in Humans and Animals. 2nd Edition, Marcel Dekker Inc., New York, 237-430.

[15] Rivas, S. and Thomas, C.M. (2005) Molecular Interactions between Tomato and the Leaf Mold Pathogen: Cladosporium fulvum. Annual Review of Phytopathology, 43, 395-436. https://doi.org/10.1146/annurev.phyto.43.040204.140224

[16] Nowicki, M., Nowakowska, M., Niezgoda, A. and Kozik, E.U. (2012) Alternaria Black Spot of Crucifers: Symptoms, Importance of Disease, and Perspectives of Resistance Breeding. Vegetable Crops Research Bulletin, 76, 5-19. https://doi.org/10.2478/v10032-012-0001-6

[17] Berkeley, M.J. (1857) Introduction to Cryptogamic Botany. Bailliere, London, 604. https://doi.org/10.5962/bhl.title.104475

[18] Zalar, P., Frisvad, J.C., Gunde-Cimerman, N., Varga, J. and Samson, R.A. (2008) Four New Species of Emericella from the Mediterranean Region of Europe. Mycologia, 100, 779-795. https://doi.org/10.3852/08-078

[19] Verweij, P.E., Varga, J., Houbraken, J., Rijs, A.J.M.M., VerduynLunel, F.M., Blijlevens, N.M.A., Shea, Y.R., Holland, S.M., Warris, A., Melchers, W.J.G. and Samson, R.A. (2008) Emericella quadrilineata as Cause of Invasive Aspergillosis. Emerging Infectious Diseases, 14, 566-572. https://doi.org/10.3201/eid1404.071157

[20] Matsuzawa, T., Tanaka, R., Horie, Y., Gonoi, T. and Yaguchi, T. (2010) Development of Rapid and Specific Molecular Discrimination Methods for Pathogenic Emericella Species. Nippon Ishinkin Gakkai Zasshi, 51, 109-116. https://doi.org/10.3314/jjmm.51.109

[21] Butinar, L., Zalar, P., Frisvad, J.C. and Gunde-Cimerman, N. (2005) The Genus Eurotium Members of Indigenous Fungal Community in Hypersaline Waters of Salterns. FEMS Microbiology Ecology, 51, 155-166. https://doi.org/10.1016/j.femsec.2004.08.002

[22] Hubka, V., Kolař́k, M., Kubátová, A. and Peterson, S.W. (2013) Taxonomic Revision of Eurotium and Transfer of Species to Aspergillus. Mycologia, 105, 912-937. https://doi.org/10.3852/12-151

[23] Inglis, P.W. and Tigano, M.S. (2006) Identification and Taxonomy of Some Entomopathogenic Paecilomyces spp. (Ascomycota) Isolates Using rDNA-ITS Sequences. Genetics and Molecular Biology, 29, 132-136. https://doi.org/10.1590/S1415-47572006000100025

[24] Steiner, B., Aquino, V.R., Paz, A.A., Silla, L.M.d.R., Zavascki, A. and Goldani, L.Z. (2013) Paecilomyces variotii as an Emergent Pathogenic Agent of Pneumonia. Case Reports in Infectious Diseases, 3.

[25] Pastor, F.J. and Guarro, J. (2006) Clinical Manifestations, Treatment and Outcome of Paecilomyces lilacinus Infections. Clinical Microbiology and Infection, 12, 948-960. https://doi.org/10.1111/j.1469-0691.2006.01481.x

[26] Egbuta, M.A., Mwanza, M., Njobeh, P.B., Phoku, J.Z. and A, C.C. (2015) Isolation of Filamentous Fungi Species Contaminating Some Nigerian Food Commodities. Journal of Food 
Research, 4, 38-50. https://doi.org/10.5539/jfr.v4n1p38

[27] Pitt, J.I. and Hocking, A.D. (1997) Fungi and Mycotoxins in Foods. In: Orchard, A.E., Ed., Fungi of Australia, Vol. 1, Introduction Fungi in the Environment, Australian Biology Research Study, Canberra, Australia, 315-342.

[28] Watanabe, T., Watanabe, Y. and Fukatsu, T. (2001) New Species of Acremonium, Cylindrocarpon and Verticillium from Soil in the Bonin (Ogasawara) Islands, Japan. Mycoscience, 42, 591-595. https://doi.org/10.1007/BF02460958

[29] Goldbeck, R., Ramos, M.M., Pereira, G.A.G. and Maugeri-Filho, F. (2013) Cellulase Production from a New Strain Acremonium strictum Isolated from the Brazilian Biome Using Different Substrates. Bioresource Technology, 128, 797-803.

https://doi.org/10.1016/j.biortech.2012.10.034

[30] Pastor, F.J. and Guarro, J. (2008) Alternaria Infections: Laboratory Diagnosis and Relevant Clinical Features. Clinical Microbiology and Infection, 14, 734-746. https://doi.org/10.1111/j.1469-0691.2008.02024.x

[31] Arvanitidou, M., Kanellou, K., Constantinidis, T. and Katsouyannopoulos, V. (2000) Higher Prevalence of Alternaria spp. in Marine and River Waters than in Potable Samples. $M i$ crobiological Research, 155, 49-51. https://doi.org/10.1016/S0944-5013(00)80022-1

[32] Horn, B.W. and Dorner, J.W. (1998) Soil Populations of Aspergillus Species from Section Flavi along a Transect through Peanut-Growing Regions of the United States. Mycologia, 90, 767-776. https://doi.org/10.2307/3761317

[33] Klich, M.A. (2002) Biogeography of Aspergillus Species in Soil and Litter. Mycologia, 94, 21-27. https://doi.org/10.2307/3761842

[34] Klich, M.A. (2002) Identification of Common Aspergillus spp, Ponson and Looijen, Wageningen. The Netherlands.

[35] Oliveira, L.G., Cavalcanti, M.A.Q., Fernandes, M.J.S. and Lima, D.M.M. (2013) Diversity of Filamentous Fungi Isolated from the Soil in the Semiarid Area, Pernambuco, Brazil. Journal of Arid Environments, 95, 49-54. https://doi.org/10.1016/j.jaridenv.2013.03.007

[36] Khan, H.A.A. and Karuppayil, M.S. (2012) Fungal Pollution of Indoor Environments and Its Management. Saudi Journal of Biological Sciences, 19, 405-426. https://doi.org/10.1016/j.sjbs.2012.06.002

[37] Panagopoulou, P., Filioti, J., Petrikkos, G., Giakouppi, P., Anatoliotaki, M., Farmaki, E., Kanta, A., Apostolakou, H., Avlami, A., Samonis, G. and Roilides, E. (2002) Environmental Surveillance of Filamentous Fungi in Three Tertiary Care Hospitals in Greece. Journal of Hospital Infection, 52, 185-191. https://doi.org/10.1053/jhin.2002.1298

[38] Nikaeen, M. and Mirhendi, H. (2008) Inactivation of Aspergillus flavus Spores in Water by Ultraviolet Irradiation. World Applied Sciences Journal, 4, 594-595.

[39] Vesper, S.J., Haugland, R.A., Rogers, M.E. and Neely, A.N. (2007) Opportunistic Aspergillus Pathogens Measured in Home and Hospital Water by Quantitative PCR. Journal of Water Health, 5, 427-431. https://doi.org/10.2166/wh.2007.038

[40] Warris, A., Voss, A., Abrahamsen, T.G. and Verweij, P.E. (2002) Contamination of Hospital Water with Aspergillus fumigatus and Other Molds. Clinical Infectious Diseases, 34, 1059-1060. https://doi.org/10.1086/339754

[41] Zalar, P., de Hoog, G., Schroers, H., Crous, P., Groenewald, J. and Gunde-Cimerman, N. (2007) Phylogeny and Ecology of the Ubiquitous Saprobe Cladosporium sphaerospermum, with Descriptions of Seven New Species from Hypersaline Environments. Studies in Mycology, 58, 157-183. https://doi.org/10.3114/sim.2007.58.06

[42] Ogórek, R., Lejman, A., Pusz, W., Miłuch, A. and Miodyńska, P. (2012) Characteristics and 
Taxonomy of Cladosporium Fungi. Mikologia Lekarska, 19, 80-85.

[43] Pratt, R.G. (2006) Comparative Survival of Conidia of Eight Species of Bipolaris, Curvularia, and Exserohilum in Soil and Influences of Swine Waste Amendments on Survival. Applied Soil Ecology, 31, 159-168. https://doi.org/10.1016/j.apsoil.2005.03.005

[44] Wang, H., Dong, H., Qian, H. and Cong, B. (2014) Laboratory Assessment of Entomopathogenic Nematode Symbiotic Bacteria to Control Maize Pest, Ostrinia furnacalis, and Fungi Diseases, Bipolaris maydis and Curvularia lunata. Journal of Asia-Pacific Entomolo$g y$, 17, 823-827. https://doi.org/10.1016/j.aspen.2014.08.002

[45] Lucas, E.M.F., Abreu, L.M., Marriel, I.E., Pfenning, L.H. and Takahashi, J.A. (2008) Phthalates Production from Curvularia senegalensis (Speg.) Subram, a Fungal Species Associated to Crops of Commercial Value. Microbiological Research, 163, 495-502. https://doi.org/10.1016/j.micres.2007.02.003

[46] Asan, A. (2011) Checklist of Fusarium Species Reported from Turkey. Mycotaxon, 116, 479.

[47] Edel-Hermann, V., Gautheron, N., Mounier, A. and Steinberg, C. (2015) Fusarium Diversity in Soil Using a Specific Molecular Approach and a Cultural Approach. Journal of Microbiological Methods, 111, 64-71. https://doi.org/10.1016/j.mimet.2015.01.026

[48] Gordon, T.R. and Martyn, R.D. (1997) The Evolutionary Biology of Fusarium oxysporum. Annual Review Phytopathology, 35, 111-128.

https://doi.org/10.1146/annurev.phyto.35.1.111

[49] Gordon, T.R., Swett, C.L. and Wingfield, M.J. (2015) Management of Fusarium Diseases Affecting Conifers. Crop Protection, 73, 28-39. https://doi.org/10.1016/j.cropro.2015.02.018

[50] Funnell-Harris, D.L. and Pedersen, J.F. (2011) Presence of Fusarium spp. in Air and Soil Associated with Sorghum Fields. Plant Disease, 95, 648-656. https://doi.org/10.1094/PDIS-09-10-0671

[51] Scheel, C., Hurst, S., Barreiros, G., Akiti, T., Nucci, M. and Balajee, S.A. (2013) Molecular Analyses of Fusarium Isolates Recovered from a Cluster of Invasive Mold Infections in a Brazilian Hospital. BMC Infectious Diseases, 13, 49. https://doi.org/10.1186/1471-2334-13-49

[52] Vigier, B., Reid, L.M., Seifert, K.A., Stewart, D.W. and Hamilton, R.I. (1997) Distribution and Prediction of Fusarium Species Associated with Maize Ear Rot in Ontario. Canadian Journal of Plant Pathology, 19, 60-65. https://doi.org/10.1080/07060669709500574

[53] Palmero, D., Iglesias, C., de Cara, M., Lomas, T., Santos, M. and Tello, J.C. (2009) Species of Fusarium Isolated from River and Sea Water of Southeastern Spain and Pathogenicity on Four Plant Species. Plant Disease, 93, 377-385. https://doi.org/10.1094/PDIS-93-4-0377

[54] Sautour, M., Edel-Hermann, V., Steinberg, C., Sixt, N., Laurent, J., Dalle, F., Aho, S., Hartemann, P., L’Ollivier, C., Goyer, M. and Bonnin, A. (2012) Fusarium Species Recovered from the Water Distribution System of a French University Hospital. International Journal of Hygiene and Environmental Health, 215, 286-292. https://doi.org/10.1016/j.ijheh.2011.11.003

[55] Jussila, J., Komulainen, H., Kosma, V.-M., Pelkonen, J. and Hirvonen, M.-R. (2002) Inflammatory Potential of the Spores of Penicillium spinulosum Isolated from Indoor Air of a Moisture-Damaged Building in Mouse Lungs. Environmental Toxicology and Pharmacology, 12, 137-145. https://doi.org/10.1016/S1382-6689(02)00018-2

[56] Sawane, A. and Saoji, A. (2004) A Report on Penicillium in the Intramural and Extramural Air of Residential Areas of Nagpur city (India). Aerobiologia, 20, 229-236.

https://doi.org/10.1007/s10453-004-1187-y 
[57] Cruz, R., Santos, C., Silva de Lima, J., Aparecida Moreira, K. and Maria de Souza-Motta, C. (2013) Diversity of Penicillium in Soil of Caatinga and Atlantic Forest Areas of Pernambuco, Brazil: An Ecological Approach. Nova Hedwigia, 97, 543-556.

https://doi.org/10.1127/0029-5035/2013/0127

[58] Dayalan, S.A.J., Darwin, P. and Prakash, S. (2011) Comparative Study on Production, Purification of Penicillin by Penicillium chrysogenum Isolated from Soil and Citrus Samples. Asian Pacific Journal of Tropical Biomedicine, 1, 15-19.

https://doi.org/10.1016/S2221-1691(11)60061-0

[59] Pryce-Miller, E., Aanensen, D., Vanittanakom, N. and Fisher, M.C. (2008) Environmental Detection of Penicillium marneffei and Growth in Soil Microcosms in Competition with Talaromyces stipitatus. Fungal Ecology, 1, 49-56. https://doi.org/10.1016/j.funeco.2008.02.002

[60] Trisuwan, K., Rukachaisirikul, V., Borwornwiriyapan, K., Phongpaichit, S. and Sakayaroj, J. (2014) Benzopyranone, Benzophenone, and Xanthone Derivatives from the Soil Fungus Penicillium citrinum PSU-RSPG95. Tetrahedron Letters, 55, 1336-1338. https://doi.org/10.1016/j.tetlet.2014.01.017

[61] Tarkkanen, A., Raivio, V., Anttila, V.-J., Tommila, P., Ralli, R., Merenmies, L. and Immonen, I. (2004) Fungal Endophthalmitis Caused by Paecilomyces variotii Following Cataract Surgery: A Presumed Operating Room Air-Conditioning System Contamination. Acta Ophthalmologica Scandinavica, 82, 232-235. https://doi.org/10.1111/j.1600-0420.2004.00235.x

[62] Luangsa-ard, J., Houbraken, J., van Doorn, T., Hong, S.-B., Borman, A.M., Hywel-Jones, N.L. and Samson, R.A. (2011) Purpureocillium, a New Genus for the Medically Important Paecilomyces lilacinus. FEMS Microbiology Letters, 321, 141-149. https://doi.org/10.1111/j.1574-6968.2011.02322.x

[63] Ogorek, R., Pusz, W., Matkowski, K. and Plaskowska, E. (2014) Assessment of Abundance and Species Composition of Filamentous Fungi in the Underground Rzeczka Complex in Sowie Mountains (Lower Silesia, Poland). Geomicrobiology Journal, 31, 900-906. https://doi.org/10.1080/01490451.2014.907380

[64] Karwowska, W., Pierzynowska, J., Janicki, A., Waszkiewicz-Robak, B. and Przybylska, A. (2004) Qualitative and Quantitative Analysis of Filamentous Fungi in Air, Food and Ochratoxin a in Human Milk. Polish Journal of Food and Nutrition Sciences, 13/54, 41-44.

[65] Viegas, C., Alves, C.L., Carolino, E., Rosado, L. and Santos, C.S. (2010) Prevalence of Fungi in Indoor Air with Reference to Gymnasiums with Swimming Pools. Indoor and Built Environment, 19, 555-561. https://doi.org/10.1177/1420326X10380120

[66] Panagopoulou, P., Filioti, J., Farmaki, E., Maloukou, A. and Roilides, E. (2007) Filamentous Fungi in a Tertiary Care Hospital: Environmental Surveillance and Susceptibility to Antifungal Drugs. Infection Control and Hospital Epidemiology, 28, 60-67. https://doi.org/10.1086/508832

[67] Ritz, K. and Young, I.M. (2004) Interactions between Soil Structure and Fungi. Mycologist, 18, 52-59. https://doi.org/10.1017/S0269915X04002010

[68] Kurek, E., Teresa Korniłłowicz-Kowalska, T., Słomka, A. and Melke, J. (2007) Characteristics of Soil Filamentous Fungi Communities Isolated from Various Micro-Relief Forms in the High Arctic Tundra (Bellsund Region, Spitsbergen). Polish Polar Research, 28, 57-73.

[69] Hughes, K.A., Bridge, P. and Clark, M.S. (2007) Tolerance of Antarctic Soil Fungi to Hydrocarbons. Science of the Total Environment, 372, 539-548. https://doi.org/10.1016/j.scitotenv.2006.09.016

[70] Sterflinger, K., Tesei, D. and Zakharova, K. (2012) Fungi in Hot and Cold Deserts with Par- 
ticular Reference to Microcolonial Fungi. Fungal Ecology, 5, 453-462. https://doi.org/10.1016/j.funeco.2011.12.007

[71] Gonçalves, A.B., Paterson, R.R.M. and Lima, N. (2006) Survey and Significance of Filamentous Fungi from Tap Water. International Journal of Hygiene and Environmental Health, 209, 257-264. https://doi.org/10.1016/j.ijheh.2005.12.001

[72] Paterson, R.R.M., Hageskal, G., Skaar, I. and Lima, N. (2009) Occurrence, Problems, Analysis and Removal of Filamentous Fungi in Drinking Water. In: De Costa, P.A.B. and Bezerra, P., Eds., Fungicides. Chemistry, Environmental Impacts and Health Effects, Nova Science Publishers Inc., New York, 379-399.

[73] Sonigo, P., De Toni, A. and Reilly, K. (2011) A Review of Fungi in Drinking Water and the Implications for Human Health. BIO Intelligence Service, France.

[74] Hayette, M.P., Christiaens, G., Mutsers, J., Barbier, C., Huynen, P., Melin, P. and de Mol, P. (2010) Filamentous Fungi Recovered from the Water Distribution System of a Belgian University Hospital. Medical Mycology, 48, 969-974.

https://doi.org/10.3109/13693781003639601

[75] Yamaguchi, M.U., Rampazzo, R., Yamada-Ogatta, S.F., Nakamura, C.V., Ueda-Nakamura, T. and Dias Filho, B.P. (2007) Yeasts and Filamentous Fungi in Bottled Mineral Water and Tap Water from Municipal Supplies. Brazilian Archives of Biology and Technology, 50, 1-9. https://doi.org/10.1590/S1516-89132007000100001

[76] Warris, A., Gaustad, P., Meis, J.F., Voss, A., Verweij, P.E. and Abrahamsen, T.G. (2001) Recovery of Filamentous Fungi from Water in a Paediatric Bone Marrow Transplantation Unit. Journal of Hospital Infection, 47, 143-148. https://doi.org/10.1053/jhin.2000.0876

[77] Okpako, E.C., Osuagwu, A.N., Duke, A.E. and Ntui, V.O. (2009) Prevalence and Significance of Fungi in Sachet and Borehole Drinking Water in Calabar, Nigeria. African Journal of Microbiological Research, 3, 56-61.

[78] Mohamed, S.A., Hamed, S.R. and Al-Wasify, R.S. (2014) Relative Diversity of Filamentous Fungi and Yeasts in Groundwater and Their Correlation to Fecal Pollution Indicators and Physicochemical Parameters. International Journal of Current Microbiology and Applied Sciences, 3, 905-919.

[79] Mbata, T.I. (2008) Isolation of Fungi in Hyper Saline Dead Sea Water. Sudanese Journal of Public Health, 3, 170-172.

[80] Varo, S., Martins, C.H., Cardoso, M.J., Sartori, F.G., Montanari, L.B. and Pires-Goncalves, R.H. (2007) [Isolation of Filamentous Fungi from Water Used in a Hemodialysis Unit. Revista da Sociedade Brasileira de Medicina Tropical, 40, 326-331. https://doi.org/10.1590/S0037-86822007000300015

[81] Schuster, E., Dunn-Coleman, N., Frisvad, J.C. and van Dijck, P.W.M. (2002) On the Safety of Aspergillus niger-A Review. Applied Microbiology and Biotechnology, 59, 426-435. https://doi.org/10.1007/s00253-002-1032-6

[82] Michelson, P. (2010) Cheese: Exploring Taste and Tradition.

[83] Van der Straat, L., Vernooij, M., Lammers, M., van den Berg, W., Schonewille, T., Cordewener, J., van der Meer, I., Koops, A. and de Graaff, L.H. (2014) Expression of the Aspergillus terreus Itaconic Acid Biosynthesis Cluster in Aspergillus niger. Microbial Cell Factories, 13, 11. https://doi.org/10.1186/1475-2859-13-11

[84] Romero, C.M., Urrutia, I.M., Reinoso, E.H. and Kiernan, M.M. (2010) Benzo[a]Pyrene Degradation by Soil Filamentous Fungi. Journal of Yeast and Fungal Research, 1, 25-29.

[85] Kurniati, E., Arfarita, N., Imai, T., Higuchi, T., Kanno, A., Yamamoto, K. and Sekine, M. (2014) Potential Bioremediation of Mercury-Contaminated Substrate Using Filamentous 
Fungi Isolated from Forest Soil. Journal of Environmental Sciences, 26, 1223-1231. https://doi.org/10.1016/S1001-0742(13)60592-6

[86] Ogawa, A., Morita, Y., Tanaka, T., Sakiyama, T. and Nakanishi, K. (1995) Production of Kojic Acid from Aspergillus oryzae var.oryzae by Membrane-Surface Liquid Culture. Biotechnology Techniques, 9, 153-156. https://doi.org/10.1007/BF00224417

[87] Jahromi, M.F., Liang, J.B., Ho, Y.W., Mohamad, R., Goh, Y.M. and Shokryazdan, P. (2012) Lovastatin Production byAspergillus terreus Using Agro-Biomass as Substrate in Solid State Fermentation. Journal of Biomedicine and Biotechnology, 2012, Article ID: 196264.

[88] Katona, S.J. (2002) Sensitivity to Quorn Mycoprotein (Fusarium venenatum) in a Mould Allergic Patient. Journal of Clinical Pathology, 55, 876-877. https://doi.org/10.1136/jcp.55.11.876-a

[89] Kaur, R., Kaur, J. and Singh, R.S. (2010) Nonpathogenic Fusarium as a Biological Control Agent. Plant Pathology Journal, 9, 79-91. https://doi.org/10.3923/ppj.2010.79.91

[90] Ahmed, H., Strub, C., Hilaire, F. and Schorr-Galindo, S. (2015) First Report: Penicillium adametzioides, a Potential Biocontrol Agent for Ochratoxin-Producing Fungus in Grapes, Resulting from Natural Product Pre-Harvest Treatment. Food Control, 51, 23-30. https://doi.org/10.1016/j.foodcont.2014.10.034

[91] Frisvad, J.C., Smedsgaard, J., Larsen, T.O. and Samson, R.A. (2004) Mycotoxins, Drugs and Other Extrolites Produced by Species in Penicillium Subgenus Penicillium. Studies in $\mathrm{My}$ cology, 49, 201-241.

[92] Barthomeuf, C., Regerat, F. and Pourrat, H. (1991) Production of Inulinase by a New Mold Penicillium rugulosum. Journal of Fermentation and Bioengineering, 72, 491-494. https://doi.org/10.1016/0922-338X(91)90063-M

[93] Laich, F., Fierro, F. and Martın, J.F. (2002) Production of Penicillin by Fungi Growing on Food Products: Identification of a Complete Penicillin Gene Cluster in Penicillium griseofulvum and a Truncated Cluster in Penicillium verrucosum. Applied and Environmental Microbiology, 68, 1211-1219. https://doi.org/10.1128/AEM.68.3.1211-1219.2002

[94] Sahasrabudhe, N.A., Lackhe, A.H. and Ranjekar, P.K. (1987) Characterization of the Purified Multifunctional Cellulase Component of P. funiculosum. FEMS Microbiology Letters, 40, 315-319. https://doi.org/10.1111/j.1574-6968.1987.tb02046.x

[95] Nelson, J.H. (1970) Production of Blue Cheese Flavor via Submerged Ermentation by Penicillium roqueforti. Journal of Agriculture and Food Chemistry, 18, 567-569. https://doi.org/10.1021/jf60170a024

[96] D’Annibale, A., Rosetto, F., Leonardi, V., Federici, F. and Petruccioli, M. (2006) Role of Autochthonous Filamentous Fungi in Bioremediation of a Soil Historically Contaminated with Aromatic Hydrocarbons. Applied and Environmental Microbiology, 72, 28-36. https://doi.org/10.1128/AEM.72.1.28-36.2006

[97] Mancera-López, M.E., Esparza-García, F., Chávez-Gómez, B., Rodríguez-Vázquez, R., Saucedo-Castañeda, G. and Barrera-Cortés, J. (2008) Bioremediation of an Aged Hydrocarbon-Contaminated Soil by a Combined System of Biostimulation-Bioaugmentation with Filamentous Fungi. International Biodeterioration \& Biodegradation, 61, 151-160. https://doi.org/10.1016/j.ibiod.2007.05.012

[98] Potin, O., Rafin, C. and Veignie, E. (2004) Bioremediation of an Aged Polycyclic Aromatic Hydrocarbons (PAHs)-Contaminated Soil by Filamentous Fungi Isolated from the Soil. International Biodeterioration \& Biodegradation, 54, 45-52. https://doi.org/10.1016/j.ibiod.2004.01.003

[99] Abbas, H.K., Weaver, M.A., Horn, B.W., Carbone, I., Monacell, J.T. and Shier, W.T. (2011) 
Selection of Aspergillus flavus Isolates for Biological Control of Aflatoxins in Corn. Toxin Reviews, 30, 59-70. https://doi.org/10.3109/15569543.2011.591539

[100] Zheng, Y., Yu, X., Zeng, J. and Chen, S. (2012) Feasibility of Filamentous Fungi for Biofuel Production Using Hydrolysate from Dilute Sulfuric Acid Pretreatment of Wheat Straw. Biotechnology for Biofuels, 5, 1-10. https://doi.org/10.1186/1754-6834-5-50

[101] Dutton, M.F. (2009) The African Fusarium/Maize Disease. Mycotoxin Research, 25, 29-39. https://doi.org/10.1007/s12550-008-0005-8

[102] Perrone, G., Susca, A., Cozzi, G., Ehrlich, K., Varga, J., Frisvad, J.C., Meijer, M., Noonim, P., Mahakarnchanakul, W. and Samson, R.A. (2007) Biodiversity of Aspergillus Species in Some Important Agricultural Products. Studies in Mycology, 59, 53-66. https://doi.org/10.3114/sim.2007.59.07

[103] Zain, M.E. (2011) Impact of Mycotoxins on Humans and Animals. Journal of Saudi Chemical Society, 15, 129-144. https://doi.org/10.1016/j.jscs.2010.06.006

[104] Jerusik, R.J. (2010) Fungi and Paper Manufacture. Fungal Biology Reviews, 24, 68-72. https://doi.org/10.1016/j.fbr.2010.04.003

[105] Mohammad, N., Alam, M.Z., Kabbashi, N.A. and Ahsan, A. (2012) Effective Composting of Oil Palm Industrial Waste by Filamentous Fungi: A Review. Resources, Conservation and Recycling, 58, 69-78. https://doi.org/10.1016/j.resconrec.2011.10.009

[106] Khokhar, I., HAIDER, M.S., Mushtaq, S. and Mukhtar, I. (2012) Isolation and Screening of Highly Cellulolytic Filamentous Fungi. Journal of Applied Sciences and Environmental Management, 16, 223-226.

[107] Archer, D.B. (2000) Filamentous Fungi as Microbial Cell Factories for Food Use. Current Opinion in Biotechnology, 11, 478-483. https://doi.org/10.1016/S0958-1669(00)00129-4

[108] Guimarães, L., Peixoto-Nogueira, S., Michelin, M., Rizzatti, A., Sandrim, V.C., Zanoelo, F.F., Aquino, A., Altino, B and Polizeli, M. (2006) Screening of Filamentous Fungi for Production of Enzymes of Biotechnological Interest. Brazilian Journal of Microbiology, 37, 474-480. https://doi.org/10.1590/S1517-83822006000400014

[109] Majumder, L., Khalil, I., Munshi, M.K., Alam, K., Rashid, H.-O., Begum, R. and Alam, N. (2010) Citric Acid Production by Aspergillus niger Using Molasses and Pumpkin as Substrates. European Journal of Biological Sciences, 2, 1-8.

[110] Max, B., Salgado, J.M., Rodríguez, N., Cortés, S., Converti, A. and Domínguez, J.M. (2010) Biotechnological Production of Citric acid. Brazilian Journal of Microbiology, 41, 862-875. https://doi.org/10.1590/S1517-83822010000400005

[111] Sahasrabudhe, N.A. and Sankpal, N.V. (2001) Production of Organic Acids and Metabolites of Fungi for Food Industry. In: George, G.K. and Dilip, K.A., Eds., Applied Mycology and Biotechnology, Elsevier, Amsterdam, 387-425. https://doi.org/10.1016/s1874-5334(01)80016-2

[112] Goswami, S., Vidyarthi, A.S., Bhunia, B. and Mandal, T. (2012) A Review on Lovastatin and Its Production. Journal of Biochemical Technology, 4, 581-587.

[113] Manzoni, M. and Rollini, M. (2002) Biosynthesis and Biotechnological Production of Statins by Filamentous Fungi and Application of These Cholesterol-Lowering Drugs. Applied Microbiology and Biotechnology, 58, 555-564. https://doi.org/10.1007/s00253-002-0932-9

[114] McLean, K.J., Hans, M., Meijrink, B., van Scheppingen, W.B., Vollebregt, A., Tee, K.L., van der Laan, J.-M., Leys, D., Munro, A.W. and van den Berg, M.A. (2015) Single-Step Fermentative Production of the Cholesterol Lowering Drug Pravastatin via Reprogramming of $\mathrm{Pe}$ nicillium chrysogenum. Proceedings of the National Academy of Sciences of the United States of America, 112, 2847-2852. https://doi.org/10.1073/pnas.1419028112 
[115] Sharmila, K., Thillaimaharani, K.A., Logesh, A.R., Sathishkumar, A. and Kalaiselvam, M. (2012) Production of Cyclosporin-A by Saprophytic Filamentous Fungus Fusarium oxysporum. International Journal of Pharmacy and Pharmaceutical Sciences, 4, 149-153.

[116] He, H., Yang, H.Y., Bigelis, R., Solum, E.H., Greenstein, M. and Carter, G.T. (2002) Pyrrocidines A and B, New Antibiotics Produced by a Filamentous Fungus. Tetrahedron Letters, 43, 1633-1636. https://doi.org/10.1016/S0040-4039(02)00099-0

[117] Goswami, S., Rani, A., Priyadarshini, R., Bhunia, B. and Mandal, T. (2012) A Review on Production of Echinocandins by Aspergillus sp. Journal of Biochemical Technology, 4, 568-575.

[118] Svahn, S.K., Goransson, U., El-Seedi, H., Bohlin, L., Larsson, J.D.G., Olsen, B. and Chryssanthou, E. (2012) Antimicrobial Activity of Filamentous Fungi Isolated from Highly Antibiotic Contaminated River Sediment. Infection Ecology and Epidemiology, 2, 11591-11597. https://doi.org/10.3402/iee.v2i0.11591

[119] Smith, H.A. (2014) Production of Antimicrobials and Antioxidants from Filamentous Fungi. Department of Biology, National University of Ireland, Ireland.

[120] Amadio, J., Casey, E. and Murphy, C. (2013) Filamentous Fungal Biofilm for Production of Human Drug Metabolites. Applied Microbiology and Biotechnology, 97, 5955-5963. https://doi.org/10.1007/s00253-013-4833-x

Submit or recommend next manuscript to SCIRP and we will provide best service for you:

Accepting pre-submission inquiries through Email, Facebook, LinkedIn, Twitter, etc.

A wide selection of journals (inclusive of 9 subjects, more than 200 journals)

Providing 24-hour high-quality service

User-friendly online submission system

Fair and swift peer-review system

Efficient typesetting and proofreading procedure

Display of the result of downloads and visits, as well as the number of cited articles

Maximum dissemination of your research work

Submit your manuscript at: http://papersubmission.scirp.org/

Or contact aim@scirp.org 